\title{
Human Gene Mapping 11
}

London Conference (1991): Eleventh International Workshop on Human Gene Mapping

\begin{abstract}
Vol. 58, 1991
S. Karger · Medical and Scientific Publishers

Basel · München · Paris · London · New $\mid$ York · New Delhi · Bangkok · Singapore -Tokyo · Sydney

All rights reserved. Readers and Subscribers')

Sponsored by the

Imperial Cancer Research Fund

Human Gene Mapping Workshops Executive Committee

at New Connaught Rooms, London, UK August 18-22,1991

Conveners

Walter Bodmer Ellen Solomon

Editors

Ellen Solomon Chris Rawlings

Human Gene Mapping Workshops Report Series Editor

Harold P. Klinger
\end{abstract}

No part of this publication may be translated into other languages, reproduced or C Copyright 1991 by S. Karger AG, P.O. Box, CH-4009 Basel (Switzerland)

utilized in any form or by any means, electronic or mechanical, including photo- Printed in Switzerland on acid-free paper by Thür AG Offsetdruck, Pratteln

copying, recording, microcopying, or by any information storage and retrieval system, without permission in writing from the publisher or, in the case of photocopying, direct payment of a specified fee to the Copyright Clearance Center (see 'Information for

Robert S. Sparkes (President) Harold P. Klinger (Secretary) Walter Bodmer Charles R. Cantor Albert de la Chapelle Jean Frézal Kenneth K. Kidd Victor A.

McKusick Peter L. Pearson Frank H. Ruddle Nobuyoshi Shimizu Thomas B. Shows

Cytogenetics and Cell Genetics Vol. 58,Nos. 1-4,1991

\section{KAIVGER}

Basel $\cdot$ München · Paris · London · New York

Received for publication December 23, 1991 New Delhi $\cdot$ Bangkok $\cdot$ Singapore $\cdot$ Tokyo $\cdot$ Sydney

Published by Cytogenetics and Cell Genetics

under the title

Human Gene Mapping 11

viii + 2200pp., 103 fig., 78 tab., 1991

Publisher: S. Karger AG

P.O. Box

CH-4009 Basel (Switzerland)

Tel. (061) 3061111

Fax(061) 3061234

Copies of 'Human Gene Mapping 1Г and of earlier Mapping Reports can be ordered only through the publisher, S. Karger AG, at the above address or in the United States from:

S. Karger Publishers, Inc. 26 West Avon Road P.O. Box 529 Farmington, CT 06085 Tel. (203) 675-7834 Fax(203)675-7302

Please Note:

How to cite this report and its content:

When referring to this report as an entity in text, it should be cited as: Human Gene Mapping 11 (1991). The complete citation for a reference list is: Human Gene Mapping 11 (1991). Cytogenet Cell Genet 58:1-2200 (1991).

Committee reports and abstracts should be cited according to author names as usual. The complete citation for a reference list is: Authors, title of report, Human Gene Mapping 11 (1991). Cytogenet Cell Genet 58: (page numbers) (1991).

Library of Congress Catalog Card Number 73-644001

Copyright 19091 by

S. Karger AG, P.O. Box, 4009 Basel (Switzerland) Printed in Switzerland on acid-free paper by Thür AG Offsetdruck, Pratteln ISBN 3-8055-5572-5

HGM11 UK Executive Committee

Sir Walter Bodmer (Chair) 
Ellen Solomon (Co-Chair)

Tim Bishop Martin Bobrow IanCraig Kay Davies John Edwards

Annals of Human Genetics

Arthritis and Rheumatism Council

Association Francaise Contre Les

Myopathies

British Heart Foundation

Cancer Research Campaign

Malcolm Ferguson-Smith Peter Goodfellow Peter Harper John Johnson Sue Povey

Granting Agencies

Commission of the European

Communities

Cystic Fibrosis Research Trust

Israel Cancer Association

Medical Research Council of Canada

Michael Probert Chris Rawlings Bette Robson Nigel Spurr

Veronica van Heyningen Bob Williamson

Muscular Dystrophy Group of Great Britain and Northern Ireland The Norwegian Cancer Society Swedish Cancer League Tuberous Sclerosis Association of Great Britain Corporate Sponsors

Amersham International pic Applied Biosystems Ltd. Beckman Instruments (UK) British Bio-Technology British Nuclear Fuels Celltech Ltd.

Duphar Laboratories Ltd. Fisons pic ICI Pharmaceuticals S. Karger AG Ladbroke Group pic

John Libbey Eurotext Ltd.

Perkin-Elmer Ltd.

Promega

SmithKline Beecham Pharmaceuticals

Sybase Inc.

Xenova Ltd.

Computing Equipment Loan and Support

Apple Computers (UK) ATS Technirent Limited University College London (Dept. Computer Science)

Jane Crowther

Simon Earthrowl Lyndon Gray Saki Hajnal David Harley

Hewlett-Packard Lancare (UK) Limited Sitka

Management and Administration Dana Pantelic

HGM 11 Computing Team and Consultants Chris Rawlings (Project Manager)

Allan Isted Mary Jennings Robert Mangan Lowie Massey

Sun Microsystems (UK) Sybase Inc. WordPerfect Corporation

Michael Probert

Maz Moazzam Ali Rahmanzadeh Julia White

Richard Lucier (Project Manager)

Kerryn Brandt Christopher Brunn John Campbell Mike Chipperfield Tom Emmel Ken Fasman

John Attwood

Genome Data Base Development Team and Consultants

Peter Pearson (Scientific Director)

Kay Gottesman Steve Grubb John Johnston Lita Kearney Bonnie Maidak David Marquette

Assistants to the Computing Team

Steve Bryant Jeremy Martinson

Diane Hinton

(HHMI Genome Program Manager)

Glenn Mason Karen Phipps Francois Schiettecatte Debbi Schneider Marv Schneider Ted Ying

Sian Renfrey

\section{Table of Content}

\section{Volume 58, No. 1-2,1991}

INTRODUCTION

E Solomon and W F Bodmer $\quad 1$

Overview of HGM11

M. Probert and C. Rawlings

Production of the HGM11 report

C. Rawlings 3

The 1991 catalog of mapped genes and report of the nomenclature committee

P.J. McAlpine, T.B. Shows, C. Boucheix, M. Huebner, and W.A. Anderson

Report of the committee on the genetic constitution of chromosome 1

G.A. Brans and N.C. Dracopoli 103 
Report of the committee on the genetic constitution of chromosome 2 N.K. Spurr and R. White 142

Report of the committee on the genetic constitution of chromosome 3 S. Naylor and B. Carritt 170

Report of the committee on the genetic constitution of chromosome 4 J.C. Murray and GJ.B. Van Ommen

Report of the committee on the genetic constitution of chromosome 5 J.J. Wasmuth, D.T. Bishop, and C.A. Westbrook 261

Report of the committee on the genetic constitution of chromosome 6 A. Ziegler, $L L$ : Field, and A.Y. Sakaguchi 295

Report of the committee on the genetic constitution of chromosome 7

L-C. Tsui and M. Farrall 337

Report of the committee on the genetic constitution of chromosome 8 H. Donis-Keller and V. Buckle 382

Report of the committee on the genetic constitution of chromosome 9 S. Povey, C. Falk, and M. Smith 403

Report of the committee on the genetic constitution of chromosome 10 N.E. Simpson and H.M. Cann 428

Report of the committee on the genetic constitution of chromosome 11 C. Junien and V. van Heyningen 459

Report of the committee on the genetic constitution of chromosome 12 I.W. Craig and O.W. McBride 555

$\mathrm{vu}$

Table of Content

Report of the committee on the genetic constitution of chromosome 13

A. Bowcock and R.T. Taggart 580

Report of the committee on the genetic constitution of chromosome 14

D.W. Cox, Y. Nakamura, and T. Gedde-Dahl Jr 605

Report of the committee on the genetic constitution of chromosome 15

T.A. Donlon and S. Malcolm 624

Report of the committee on the genetic constitution of chromosome 16

S.T. Reeders, CE. Hildebrand, and G.R. Sutherland 643

Report of the committee on the genetic constitution of chromosome 17

E. Solomon and D.H. Ledbetter 686

Report of the committee on the genetic constitution of chromosome 18

M.M. Le Beau and A.H.M. Geurts van Kessel 739

Report of the committee on the genetic constitution of chromosome 19

H.H. Ropers and M.A. Pericak-Vance 751

Report of the committee on the genetic constitution of chromosome 20

K.H. Grzeschik and M.H. Skolnick 785

Report of the committee on the genetic constitution of chromosome 21

D.R. Cox and N. Shimizu 800

Report of the committee on the genetic constitution of chromosome 22

B.S. Emanuel, M.L. Budarf, and B.R. Seizinger

Report of the committee on the genetic constitution of the X chromosome

K.E. Davies, J-L. Mandel, AP. Monaco, R.L. Nussbaum, and H.F. Willard 853

Report of the committee on the genetic constitution of the Y chromosome

J. Weissenbach and P.N. Goodfellow 967

Volume 58, No. 3-4,1991

Report of the committee on clinical disorders, chromosome aberrations and uniparental disomy

J,Frézal and A.Schinzel 986

Report of the committee on chromosome changes in neoplasia

F. Mitelman, Y. Kaneko, and J. Trent 1053

Report of the committee on chromosome and gene loss in human neoplasia

BJR. Seizinger, H. P. Klinger, C. Junien, Y. Nakamura, M. Le Beau, W. Cavenee, B. Emanuel, B. Ponder, S. Naylor, F. Mitelman,

D. Louis, A. Menon, I. Newsham, J. Decker, M. Kaelbling, I. Henry, A. v. Deimling

1080

Report of the committee on linkage and gene order

BJ.B. Keats, S.L. Sherman, and J. Ott 1097

Report of the committee on human mitochondrial DNA

D.C Wallace, M.T. Lott, A. Torroni and J.M. Shoffner 1103

Report of the committee on comparative gene mapping

S.J. O'Brien and J.A. Marshall Graves $\quad 1124$ 
Table of Content viii

Report of the comparative committee for human, mouse and other rodents

M.T. Davisson, P.A. Lalley, J. Peters, D.P. Doolittle, A.L. Hillyard, and A.G. Searle

Report of the DNA committee and catalogues of cloned and mapped genes, markers formatted for PCR and

DNA polymorphisms

R. Williamson, A. Bowcock, K. Kidd, P. Pearson, J. Schmidtke, P. Ceverha, M. Chipperfield, D.N. Cooper,

C. Coutelle, J. Hewitt, K. Klinger, K. Langley, J. Beckmann, M. Tolley and B. Maidak 1190

Table 1: Numbers of New Loci 1191

Table 2: Cloned Genes 1199

Table 3: Reference Markers

1246

Table 4: Polymorphic markers and DNA segments

Table 5: ASO and PCR Sequences 1662

Table 6: Polymorphic PCR markers 1684

Table 7: Physical Mapping 1697

Table 8: Human Sequence Tagged Microsatellite Sites

References $\quad 1718$

Report of the informatics committee

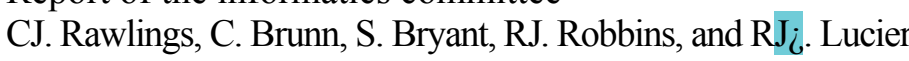

\section{Workshop Reports}

Attributes of markers on linkage and physical maps

M,Skolnick 1839

cDNA

NAffara $\quad 1841$

Combining genetic and physical maps

S.L. Sherman 1842

Enabling technologies

T.Monaco 1845

Multifactorial traits

P. Fain 1847

Coding Sequences in Genomic DNA

A-M. Frischauf 1849

Abstracts of workshop presentations 1850

Index of authors of abstracts 2157

Index of GDB source ID numbers 2169

Subject Index

Participants

2184 